\title{
HUMIC ACID ON GERMINATION AND VIGOR OF CORN SEEDS ${ }^{1}$
}

\author{
LENNIS AFRAIRE RODRIGUES ${ }^{2}$, CHARLINE ZARATIN ALVES ${ }^{2 *}$, CARLOS HENRIQUE QUEIROZ REGO $^{2}$, \\ TIAGO ROQUE BENETOLI DA SILVA ${ }^{3}$, JOSUÉ BISPO DA SILVA ${ }^{4}$
}

\begin{abstract}
The development of technologies to increase stand establishment efficiency and seed vigor, as well as to maximize profits, is of fundamental importance for the sustainability of agriculture. Products based on humic substances, such as humic acids, have been recently used in Brazilian agriculture to produce seedlings with high vigor, which positively influences the establishment of the initial stand. Thus, this study aimed to evaluate the effect of treatment of corn seeds with a commercial humic acid-based product, Humykos ${ }^{\circledR}(18 \%$ of humic acid content), on germination and seedling vigor. The treatments consisted of six doses $\left(0,100,200,300,400\right.$, and $500 \mathrm{~mL} 100 \mathrm{~kg}^{-1}$ seed) of Humykos ${ }^{\circledR}$, and the treated seeds were analyzed for germination and vigor (first count, emergence, emergence speed index, length, and dry mass of shoots and roots). Our results show that humic acid promotes greater seedling growth and increased shoot dry mass in corn; in addition, it has a positive influence on the emergence speed index up to a dose $158 \mathrm{~mL} 100 \mathrm{~kg}^{-1}$ seeds.
\end{abstract}

Keywords: Organic acids. Biostimulants. Physiological quality. Zea mays L..

\section{ÁCIDO HÚMICO NA GERMINAÇÃO E VIGOR DE SEMENTES DE MILHO}

RESUMO - O desenvolvimento de tecnologias que visam aumentar a eficiência do estabelecimento de estande e incremento no vigor das sementes, bem como maximizar os lucros é de fundamental importância para a sustentabilidade da agricultura. Produtos à base de substâncias húmicas, tais como ácidos húmicos, vêm sendo utilizados recentemente na agricultura brasileira, atuando em processos fisiológicos, de tal forma a garantir plântulas com elevado vigor, o que influencia positivamente no estabelecimento do estande inicial da cultura. Dessa forma, esse trabalho teve como objetivo avaliar o efeito do tratamento de sementes de milho com produto comercial fonte de ácido húmico, na germinação e vigor de plântulas. Os tratamentos foram constituídos de seis doses $\left(0,100,200,300,400\right.$ e $500 \mathrm{~mL} 100 \mathrm{~kg}^{-1}$ de sementes) do produto comercial Humykos ${ }^{\circledR}(18 \%$ de ácido húmico). As sementes tratadas foram analisadas quanto à germinação e vigor (primeira contagem de germinação, emergência, índice de velocidade de emergência, comprimento e massa seca de parte aérea e raiz). O ácido húmico promove maior crescimento das plântulas e aumento da massa seca da parte aérea do milho, além de ter influência positiva no índice de velocidade de emergência, até a dose $158 \mathrm{~mL} 100 \mathrm{~kg}^{-1}$ de sementes.

Palavras-chave: Ácidos orgânicos. Bioestimulantes. Qualidade fisiológica. Zea mays L..

\footnotetext{
*Corresponding author

${ }^{1}$ Received for publication in 03/10/2016; accepted in 06/20/2016.

${ }^{2}$ Department of Agronomy, Universidade Federal de Mato Grosso do Sul, Chapadão do Sul, MS, Brazil; lennisrodrigues@gmail.com, charline.alves@ufms.br, c.arloshenr@hotmail.com.

${ }^{3}$ Department of Science Agronomic, Universidade Estadual de Maringá, Umuarama, PR, Brazil; trbsilva@uem.br.

${ }^{4}$ Science Center Biological and Nature, Universidade Federal do Acre, Rio Branco, AC, Brazil; josuebispo@bol.com.br.
} 


\section{INTRODUCTION}

Humic substances (HS) are the main decomposition products of plant and animal tissues. Based on their solubility, they are classified as fulvic acids (fraction soluble in alkali and acid) and humic acids (fraction soluble in alkali and insoluble in acid) (BALDOTTO; BALDOTTO, 2014).

These substances improve the biological and structural characteristics of the soil and also the plants, their effects varying among different plant species, which respond differently at each stage of their development to the dose and method of application of humic acid (CANELLAS; SANTOS, 2005). The activity mechanism of humic acid in promoting plant growth is not fully understood, and the beneficial effects to plants is difficult to comprehend due to its chemical heterogeneity (VESELÁ et al., 2005; MUSCOLO et al., 2007).

The most established explanations for the beneficial effects of HS are related to their positive influence on ion transport, which improves cell permeability, thereby affects absorption. They also promote increased respiration and speed of enzymatic reactions of the Krebs cycle, resulting in increased ATP production, altering directly plant metabolism and, consequently, may significantly influence growth and development (ZANDONADI; CANELLAS; FAÇANHA, 2007, CHEN; CLAPP; MAGEN, 2004).

The increase in absorption rates can be explained by the activation of $\mathrm{H}+$-ATPase present in the plasma membrane (CANELLAS; FAÇANHA, 2004), acting on two mechanisms essential to plant growth, through the energy supply to the secondary systems in the translocation of ions and by increasing plasticity of the cell wall, thus allowing cell growth and division (RODDA et al., 2006).

Although HS are present naturally in soils, products based on HS, such as organic fertilizers, soil conditioners and physiological stimulators, have been used in Brazilian agriculture in recent times. In the national market, there is a variety of products based on humic acids obtained from mineral deposits (leonardite, lignite, etc.), organic soil (peatlands) or humification of plant residues (BENITES; POLIDORO; MENEZES, 2006). The use of products based on HS, such as humic acid, can positively interfere with the physiological processes of the plant in such a way to ensure high seedling vigor, which positively affects the establishment of the initial stand.

Studies conducted in controlled environments or in nutrient solutions have demonstrated the positive effects of HS on the physiology and growth of plants. Several authors have obtained positive results in tomato, lettuce, and ryegrass utilizing HS (BERNARDES; REIS; RODRIGUES, 2011; RODDA et al., 2006; SILVA et al., 2000). The positive effect of $\mathrm{HS}$ on germination and seed physiological quality has recently been reported in leucaena (BALDOTTO et al., 2013) and annual crops such as sorghum (VENDRUSCOLO; SANTOS; ALVES, 2014).

Considering the importance of corn in Brazilian agriculture, and the discovery of new substances that can be used to maximize yields, this study aimed to evaluate the effect of seed treatment with a commercial humic acid-based product on germination and vigor of corn seedlings.

\section{MATERIAL AND METHODS}

The experiments were conducted at the Seed Technology Laboratory in the campus of the Chapadão do Sul, University Federal of Mato Grosso do Sul (UFMS), using corn (Zea mays L.) seeds, variety 30F53. Seeds were treated with $0,100,200$, 300,400 , and $500 \mathrm{~mL} \mathrm{~kg}^{-1}$ seeds of Humykos ${ }^{\circledR}$, which is composed of $18 \%$ humic acid, $3 \%$ fulvic acid, $98 \%$ soluble humate, and $12 \%$ organic carbon.

The product was applied directly on to the seeds kept in plastic bags using a volumetric pipette, and shaken vigorously for one minute to ensure even coating. Seeds were then submitted to germination and vigor tests, where first count, emergence, emergence speed index, length and dry mass of roots and shoots of seedlings were measured.

For the germination test, 50 seeds were used for each treatment in four replicates. Seeds were packed in germitest paper rolls pre-moistened with distilled water 2.5 times the weight of the dry seeds, and kept in a germinator at a constant temperature of $25{ }^{\circ} \mathrm{C}$. The first count of germination was performed four days and the final count was performed seven days after starting the test, expressed as mean percentage of normal seedlings (BRASIL, 2009).

In the seedling length test, there were four replicates of 20 seeds per treatment, packed in rolls previously moistened with distilled water 2.5 times the weight of the dry seeds, which were grouped, closed in plastic bags and placed in a germinator at a constant temperature of $25^{\circ} \mathrm{C}$. The length of normal seedlings was measured seven days after the installation of the test, with the shoot and root measured separately. The values were summed and divided by the number of measured normal seedlings.

Seedlings used for the evaluation of dry mass were from the length test. For this, the samples were dried in a forced circulation stove at $80{ }^{\circ} \mathrm{C}$ for 24 hours, weighed and divided by the number of normal seedlings to give the mean mass per seedling.

For the emergence test, 200 seeds per treatment in four replications of 50 were put in expanded polystyrene trays, kept in the greenhouse and irrigated twice a day, with daily assessments until the tenth day after sowing. The emergence speed index (ESI) has been developed together with 
the emergence test, according to the formula proposed by Maguire (1962).

The experimental design was completely randomized and the data were statistically analyzed by analysis of variance test and polynomial regression at $5 \%$ probability.

\section{RESULTS AND DISCUSSION}

According to the variance analysis (Table 1), no significant effect of dose of Humykos ${ }^{\circledR}$ on the first count and germination (Table 1) was observed. Nicchio et al. (2013) and Vendruscolo, Santos and Alves (2014) did not observe a positive effect of increasing doses of humic acid on first count and germination in seed corn and sorghum, respectively. Šerá and Novák (2011) studied the effect of humic acid on Chenopodium album L. seeds and observed only $10 \%$ to $20 \%$ increase in germination. This corresponds well with the present data and is probably associated with features like high germination and no dormancy in the cultivated species, making the effect of humic acid on germination not significant.

Table 1. Germination (G), first count (FC), emergence (E), emergence speed index (ESI), shoot length (SL), root length (RL), dry mass of shoot (DMS) and root dry mass (RDM) of corn seedlings in response to different doses of Humykos ${ }^{\circledR}$.

\begin{tabular}{|c|c|c|c|c|c|c|c|c|}
\hline $\begin{array}{l}\text { Doses } \\
\left(\mathrm{mL} \mathrm{kg}^{-1}\right)\end{array}$ & $\begin{array}{l}\mathrm{G} \\
(\%)\end{array}$ & $\begin{array}{l}\mathrm{FC} \\
(\%)\end{array}$ & $\begin{array}{l}\mathrm{E} \\
(\%)\end{array}$ & $\begin{array}{c}\text { ESI } \\
-\end{array}$ & $\begin{array}{l}\mathrm{SL} \\
(\mathrm{cm})\end{array}$ & $\begin{array}{l}\mathrm{RL} \\
(\mathrm{cm})\end{array}$ & $\begin{array}{l}\text { DMS } \\
(\mathrm{mg})\end{array}$ & $\begin{array}{l}\text { RDM } \\
(\mathrm{mg})\end{array}$ \\
\hline 0 & 89 & 87 & 97 & 4.68 & 16.17 & 26.67 & 54.10 & 38.75 \\
\hline 100 & 88 & 86 & 96 & 4.59 & 16.17 & 27.92 & 55.02 & 37.67 \\
\hline 200 & 93 & 91 & 97 & 4.71 & 15.57 & 24.62 & 52.22 & 31.60 \\
\hline 300 & 92 & 91 & 99 & 4.66 & 18.25 & 25.65 & 58.80 & 33.22 \\
\hline 400 & 92 & 90 & 99 & 4.63 & 18.82 & 26.70 & 59.50 & 32.45 \\
\hline $\begin{array}{l}\frac{500}{\mathrm{~F}}-\overline{-} \\
\overline{\mathrm{C}} \overline{\mathrm{V}} \overline{(\%)}\end{array}$ & $-\frac{95}{2.10}$ & $\frac{94}{2.1}$ & & 4.34 & $\begin{array}{r}19.52 \\
20.51 \\
-4.18\end{array}$ & $-\frac{26.52}{2} \cdot \frac{5}{3} \cdot \frac{4^{\pi}}{59}$ & $\begin{array}{l}61.82 \\
-\frac{6.67}{5.01}\end{array}$ & $\begin{array}{l}33.82 \\
-3.81 \\
-8.66\end{array}$ \\
\hline
\end{tabular}

${ }^{\text {ns }}$ Not significant. *Significant at $5 \%$ probability.

Lopes and Macedo (2008) and Mota et al. (2015) working with Brassica pekinensis L. and Myracrodruon urundeuva Fr. All. seeds, respectively, observed a low rate of germination when larger doses of soil fertilizers with humic acid were used. Thomazini et al. (2011) also found that higher doses of the fertilizer Fertium ${ }^{\circledR}$ were not favorable for the initial development of sunflower seedlings. The inhibitory effect of humic acid is caused when the applied dose is high, which is detrimental for the germination of some species. Another factor that is not favorable for germination is the source of humic acid used; as some sources of humic acid from the decomposition of conifers are responsible for allelopathic effects on germination of some species (MUSCOLO et al., 2007). Humic acid specifically influences the germination of different plant species depending on its source and dose, making it a subject of further research to better understand the mode of action to develop specific protocols for each culture.

For shoot length, it was observed that the data adjusted to the quadratic equation (Figure 1A), so that higher product dose resulted in longer shoots. The benefit of humic acid to shoot growth may be explained by its beneficial effect on plant respiration, i.e., increasing ATP production by stimulating oxidative phosphorylation, with a consequent increase in the absorption and transport of nutrients and also in the biosynthesis of compounds, which results in further shoot development (SILVA et al., 1999). According to Aguiar et al. (2009), the stimulation of root growth by HS may be related to their diversity and structural functionality and their similarity with biostimulant substances.

In beans, Rosa et al. (2009) found a significant positive effect of increasing doses of HS on shoot growth. According to the authors, HS can influence plant growth and development by directly modifying the biochemical processes. Corroborating these results, Bernardes, Reis and Rodrigues (2011) had higher values of shoot length in tomato when used a product with humic and fulvic acid. Marques Júnior et al. (2008) also found that the positive effect on the growth of sugarcane stalks was due to humic acids derived from vermicompost.

For root length there was no statistical difference, corroborating the results by Rosa et al. (2009), who found no significant positive effect of HS, extracted from coal, on length, area and radius of bean roots. However, according to Silva et al. (1999), corn and other cereals may be more responsive to $\mathrm{HS}$, as greater root growth of corn plants in the presence of coal-derived HS, was found. This was not observed in this study, corroborating the data by Nicchio et al. (2013). In contrast, Rodda et al. (2006), using HS derived from vermicompost manure and sugarcane bagasse, observed significant development of the root system in lettuce (140-150\%) after treatments with HS. The same response pattern was found in studies on ryegrass (SILVA et al., 2000). In addition to greater root development, Arancon et al. (2006) also described positive correlations between flower and fruit 
production in pepper and strawberry and humic acid treatments extracted from food waste vermicompost. The stimulation of root growth is mostly related to the bioactivity of HS, which may have auxin-like effects on plants, with activation of $\mathrm{H}^{+}$-ATPases in the plasma membrane (CANELLAS; FAÇANHA, 2004). In tomato, Bernardes, Reis and Rodrigues (2011) and Silva et al. (2011) showed the stimulation of root growth by the application of HS from vermicompost. Cordeiro, Fernandes and Souza
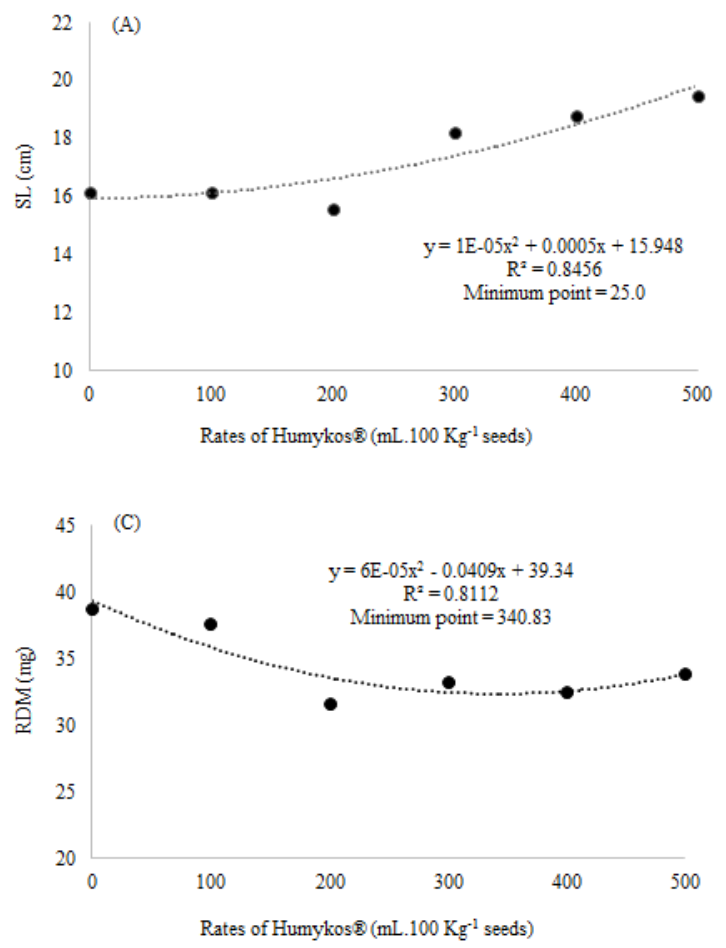

(2010) stated that the influence of HS in the development of the root system may be due to the stimulating effect of humic acid, similar to phytohormones. However, all these studies were conducted in nutrient solutions or in sandboxes, allowing various effects of humic acid on the substrate, i.e., interfering with the permeability of root cell walls, thus intervening with the absorption of nutrients and consequently influencing root growth.
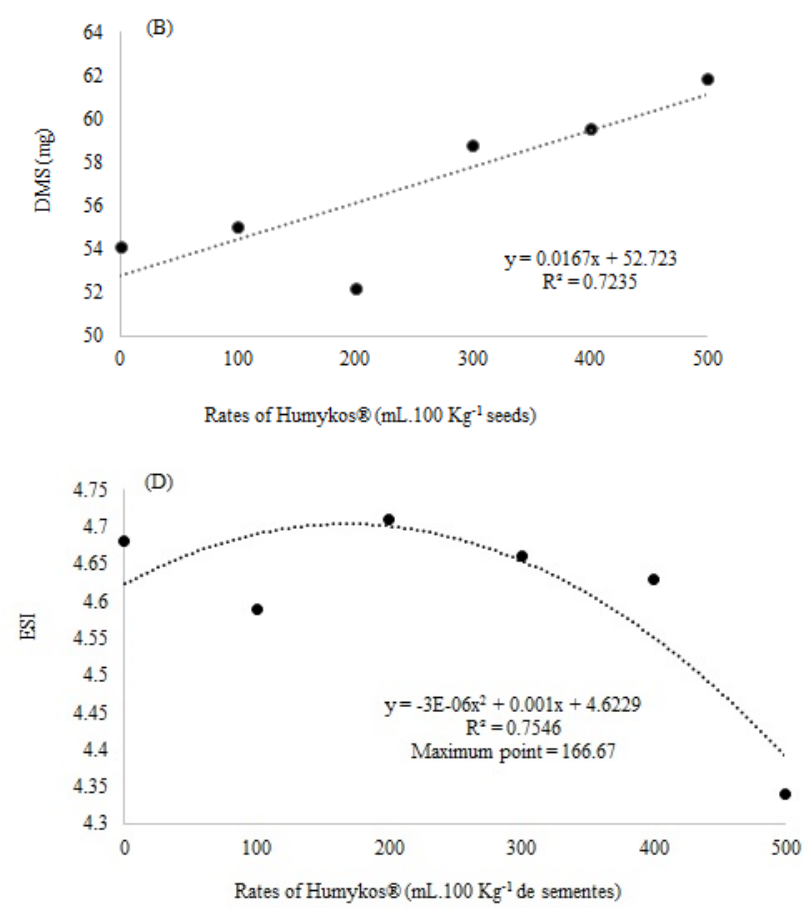

Figure 1. Shoot length (A), dry mass of shoot (B), root dry mass (C) and emergence speed index (D) of corn seedlings in response to doses of Humykos ${ }^{\circledR}$.

For the dry mass of shoots, it was found that the data adjusted to the linear equation (Figure 1B), providing an increase of $14.28 \%$ at a dose of $500 \mathrm{~mL}$ $100 \mathrm{~kg}^{-1}$ seeds compared to the control. Using nutrient solution in corn, Silva et al. (1999) showed that, regardless of the source of HS used, there was an increase in the dry mass of shoots with increasing doses of HS'. Rosa et al. (2009) found a linear positive dose-response effect of HS on the dry mass of bean shoots, the maximum dose showing an increase of $41 \%$ compared to the control. In contrast, Pinheiro, Silva and Furtini Neto (2010) observed a negative relationship between applied humic acid concentration and the dry mass of shoots in eucalyptus seedlings.

Increasing Humykos ${ }^{\circledR}$ doses negatively affected the dry mass of corn roots (Figure 1C), and the data adjusted to the quadratic equation. In contrast, Silva et al. (1999) revealed an increase in dry root mass of corn in response to HS. Similarly, in experiments with ryegrass, Silva et al. (2000) found an increase of $49.23 \%$ in the dry mass of roots. Rosa et al. (2009) also observed a linear increase of $41 \%$ compared to the control, and the same was found for tomato seedlings by Bernardes, Reis and Rodrigues (2011).

The development of the root system is related to the structure and the water-retaining capacity of the substrate which may have influenced the studied variables. Dry mass increase of the root system can be attributable to humic acid in tests that used nutrient solutions or substrates; thus, it is possible that the variation of responses in this study is influenced by the growing method.

The emergence of corn seedlings was not affected by doses of Humykos ${ }^{\circledR}$; however, ESI significantly adjusted to the quadratic equation (Figure 1D). The correlation was positive up to a dose of $158 \mathrm{~mL} 100 \mathrm{~kg}^{-1}$ seeds, above which the ESI values decreased, that is, higher doses reduced the speed of emergence of seedlings.

According to Aragão, Dantas and Alves (2003), the use of humic acids improves the performance of seedlings by accelerating their 
emergence speed and enhancing the vigor of the seeds of several species; therefore, the use of such biologically active chemicals may contribute to enhanced seed vigor. Freitas et al. (2012) in guava seeds (Psidium guajava L.) also observed an increase in ESI due to HS. Paksoy, Türkmen and Dursun (2010) found that there was a significant increase in okra seedling emergence with high doses of humic acid, while potassium slightly interfered with seedling emergence. However, Thomazini et al. (2011) observed that the use of soil fertilizers based on HS did not influence the ESI of sunflower seedlings (Helianthus annuus L.).

Many studies demonstrate beneficial responses to HS in several plant species, but it is also evident that plants respond differently, and that these variations depend on several other factors such as developmental stage, mode of application and type of HS. In general, HS culminate in the growth of the shoot and root system, as found in this study. Rapid development of seedlings of annual crops in the early stage is very important, because it ensures the ideal stand; furthermore, the initial vigor of the seedling may lead to more vigorous adult plants, contributing to increase in productivity. Thus, products formulated with HS are promising targets for future research aiming at their wide use in agriculture.

\section{CONCLUSION}

Humic acid promotes greater seedling growth and increased shoot dry mass in corn seedlings, and has a positive influence on their emergence speed index up to a dose of $158 \mathrm{~mL} 100 \mathrm{~kg}^{-1}$ seeds.

\section{REFERENCES}

AGUIAR, N. O. et al. Distribuição de massa molecular de ácidos húmicos e promoção do crecimento radicular. Revista Brasileira de Ciência do Solo, Viçosa, v. 33, n. 1, p. 1613-1623, 2009.

ARAGÃO, C. A.; DANTAS, B. F.; ALVES, E. Atividade aminolítica e qualidade fisiológica de sementes armazenadas de milho super doce tratadas com ácido giberélico. Revista Brasileira de Sementes, Pelotas, v. 25, n. 1, p. 43-48, 2003.

ARANCON, N. Q. et al. Effects of humic acids from vermicomposts on plant growth. European Journal of Soil Biology, Braunschweig, v. 42, n. 1, p. 65-69, 2006.

BAldotto, M. A.; BAldotTo, L. E. B. Ácidos Húmicos. Revista Ceres, Viçosa, v. 61, n. 1, p. 856-881, 2014.
BALDotTo, M. A. et al. Frações da matéria orgânica e propriedades redox de substâncias húmicas em sedimentos de oceanos profundos. Química Nova, São Paulo, v. 36, n. 9, p. 1288-1295, 2013.

BENITES, V. M.; POLIDORO, J. C.; MENEZES, C. C. Aplicação foliar de fertilizante orgânico mineral e soluções de ácido húmico em soja sob plantio direto. Rio de Janeiro: Embrapa Solos, 2006. 6 p. (Embrapa Solos. Comunicado técnico, 35).

BERNARDES, J. M.; REIS, J. M. R.; RODRIGUES, J. F. Efeito da aplicação de substância húmica em mudas de tomateiro. Global Science and Technology, Rio Verde, v. 4, n. 3, p. 92-99, 2011.

BRASIL. Ministério da Agricultura, Pecuária e Abastecimento. Regras para análise de sementes. Ministério da Agricultura, Pecuária e Abastecimento. Secretaria de Defesa Agropecuária. Brasília, DF: Mapa/ACS, 2009. 395 p.

CANELlAS, L. P.; FAÇANHA, A. R. Chemical nature of soil humified fractions and their bioactivity. Pesquisa Agropecuária Brasileira, Brasília, v. 39, n. 3, p. 233-240, 2004.

CANELlAS, L. P.; SANTOS, G. A. Humosfera tratado preliminar sobre a química das substâncias húmicas. Campos dos Goytacazes, RJ: UENF, 2005. $309 \mathrm{p}$.

CHEN, Y.; CLAPP, C. E.; MAGEN, H. Mechanisms of plant growth stimulation by humic substances: the role of organoiron complexes. Soil Science and Plant Nutrition, v. 50, n. 2, p. 1089-1095, 2004.

CORDEIRO, F. C.; FERNANDES, M. S.; SOUZA, S. R. Influência dos ácidos húmicos no metabolismo vegetal pode ser considerada uma resposta auxínica? Revista Universidade Rural: Série Ciências da Vida, Seropédica, v. 30, n. 2, p. 111-131, 2010.

FREITAS, A. R. et al. Germinação de sementes de goiaba em função dos substratos e regime de temperatura. Enciclopédia biosfera, Goiânia, v. 8, n. 14, p. $616,2012$.

LOPES, J. C; MACEDO, C. M. P. Germinação de sementes de couve chinesa sob influência do teor de água, substrato e estresse salino. Revista Brasileira de Sementes, Londrina, v. 30, n. 3, p. 79-85, 2008.

MAGUIRE, J. D. Speed of germination aid in selection and evaluation for seedling and vigour. Crop Science, Madison, v. 2, n. 2, p. 176-177, 1962. 
MARQUES JÚNIOR, R. B. et al. Promoção de enraizamento de microtoletes de cana-de-açúcar pelo uso conjunto de substâncias húmicas e bactérias diazotróficas. Revista Brasileira de Ciência do Solo, Viçosa, v. 32, n. 1, p. 1121-1128, 2008.

MOTA, A. R. et al. Efeito da substância húmica na germinação de sementes de Myracrodruon urundeuva Fr. All. Revista Verde, Pombal, v. 10, n. 3, p. 26-30, 2015.

MUSCOLO, A. et al. Biological activity of humic substances is related to their chemical structure. Soil Science Society of America Journal, v. 71, n. 1, p. 75-85, 2007.

NICCHIO, B. et al. Ácido húmico e bioativador no tratamento de sementes de milho. Journal of Agronomic Sciences, Umuarama, v. 2, n. 2, p. 6173, 2013.

PAKSOY, M.; TÜRKMEN, O.; DURSUN, A. Effects of potassium and humic acid on emergence, growth and nutrient contents of okra (Abelmoschus esculentus L.) seedling under saline soil conditions. African Journal of Biotechnology, Abraka, v. 9, n. 33, p. 5343-5346, 2010.

PINHEIRO, G. L.; SILVA, C. A.; FURTINI NETO, A. E. Crescimento e nutrição de clone de eucalipto em resposta à aplicação de concentrações de ácido húmico. Revista Brasileira de Ciência do Solo, Viçosa, v. 34, n. 4, p. 1217-1229, 2010.

RODDA, M. R. C. et al. Estímulo no crescimento e na hidrólise de ATP em raízes de alface tratadas com humatos de vermicomposto. Revista Brasileira de Ciência Solo, Viçosa, v. 30, n. 4, p. 649-656, 2006.

ROSA, C. M. et al. Efeito de substâncias húmicas na cinética de absorção de potássio, crescimento de plantas e concentração de nutrientes em Phaseolus vulgaris L.. Revista Brasileira de Ciência do Solo, Viçosa, v. 33, n. 4, p. 959-967, 2009.

ŠERÁ, B.; NOVÁK, F. The effect of humic substances on germination and early growth of Lamb's Quarters (Chenopodium album agg.). Biologia, Versita, v. 66, n. 3, p. 470-476, 2011.

SILVA, R. M. et al. Crescimento da parte aérea e do sistema radicular do milho cultivado em solução nutritiva adicionada de substâncias húmicas. Revista Brasileira de Agrociência, Pelotas, v. 5, n. 2, p. 101-110, 1999.

SILVA, A. C. et al. Promoção do crescimento radicular de plântulas de tomateiro por substâncias húmicas isoladas de turfeiras. Revista Brasileira de Ciência do Solo, Viçosa, v. 35, n. 1, p. 1609-1617, 2011.

SILVA, R. M. et al. Desenvolvimento das raízes do azevém cultivado em solução nutritiva completa, adicionada de substâncias húmicas, sob condições de casa de vegetação. Revista Brasileira de Zootecnia, Viçosa, v. 29, n. 6, p. 1623-1631, 2000.

THOMAZINI, A. et al. Influência do condicionador de solo Fertium $^{\circledR}$ na germinação e no desenvolvimento de plântulas de Helianthus annuus L.. Revista Verde, Pombal, v. 6, n. 2, p. 238-242, 2011.

VENDRUSCOLO, E. P.; SANTOS, O. F.; ALVES, C. Z. Substâncias húmicas na qualidade fisiológica de sementes de sorgo. Journal of Agronomic Sciences, Umuarama, v. 3, n. 2, p. 169-177, 2014.

VESELÁ, L. et al. Structure and properties of natural humic substances of the oxihumolite type. Chemické Listy, v. 99, n. 1, p. 711-717, 2005.

ZANDONADI, D. B.; CANELLAS, L. P.; FAÇANHA, A. R. Indolacetic and humic acids induce lateral root development through a concerted plasmalemma and tonoplast $\mathrm{H}+$ pumps activation. Planta, Berlin, v. 225, n. 6, p. 1583-1595, 2007. 